\title{
Induction or no induction: in modern era of triple immunosuppression
}

\author{
Mital Parikh
}

Department of Nephrology, Shree Krisjhna Hospital, Karamsad, India

Background: Majority of kidney transplants today use induction agents to reduce the incidence of acute rejections, however there has been simultaneous increase in infections and costs of transplantation.

Methods: We retrospectively collected data of renal transplant patients from April 2007 to August 2012 and analyzed them with respect to whether they received any induction agent or not and compared their outcomes over 5 years in terms of rejection episodes, graft loss, mortality, infections.

Results: We could extract data of 379 patients. ATG (Thymo) was given in 29 patients, Basiliximab (Simulect) in 42 and Daclizumab was given to 22 patients. Their mean age was $36.57 \pm 11.5$ years with mean follow-up duration of $46.2 \pm 29.5$ months. There was significant reduction in acute rejections at 1 month $(4.3 \%$ vs. $17.48 \%, P=0.001)$ and lower mean serum creatinine at 5 year post transplant $(1.3 \mathrm{mg} / \mathrm{dL}[0.8-1.8] \mathrm{vs} .1 .43 \mathrm{mg} / \mathrm{dL}[0.8-2.07])$ in the induction group compared to no induction group, but overall there was no significant difference in rejection episodes, patient and graft survival. There was significantly higher total infections ( $41.93 \%$ vs. $26.22 \%, P=0.006)$, cytomegalovirus (CMV) infection (11.8\% vs. $3.14 \%, P=0.001)$ and trend towards higher $B K V(5.3 \%$ vs. $1.3 \%, P=0.03)$ in the induction group.

Conclusions: In the present scenario of triple immunosuppression, the use of induction agents is associated with increased costs and serious infections like CMV with no significant benefits of improved patient and graft survival.

Corresponding author: Mital Parikh

E-mail: mitalparikh1@yahoo.com

(C) The Korean Society for Transplantation

This is an Open Access article distributed under the terms of the Creative Commons Attribution Non-Commercial License (http://creativecommons.org/licenses/by-nc/4.0/) which permits unrestricted non-commercial use, distribution, and reproduction in any medium, provided the original work is properly cited. 